\title{
Ese efímero objeto de deseo: happening y arte en acción en De donde son los cantantes, de Severo Sarduy ${ }^{1}$
}

\author{
M. Alejandra Aguilar Dornelles ${ }^{2}$ \\ Universidad de Albany-SUNY \\ ORCID ID: 0000-0002-9479-8775
}

Recibido: 12 de enero Aceptado: 25 de febrero

\section{Resumen}

Este artículo analiza la incorporación crítica de las experimentaciones estéticas del action painting y del happening en De donde son los cantantes como estrategia de disidencia frente a la concepción de la literatura comprometida. Concebir la novela como "evento" en el que confluyen diversas materialidades y temporalidades, me lleva a proponer la existencia de un diálogo con la estética del happening. Sugiero que al incorporar los debates críticos sobre la naturaleza y el rol del arte en la sociedad de los años sesenta, De donde son los cantantes se propone como arte en acción enfatizando la potencialidad del lenguaje para generar placer y requerir que el lector participe en la creación del sentido.

\section{Abstract}

This article analyzes the critical incorporation of the aesthetic of action painting and happening in De donde son los cantantes as a strategy of dissidence against the conception of literature placed at the service of political agendas. By conceiving the novel as an "event" in which diverse materialities and temporalities come together, I propose to read the novel as art in action. I suggest that by incorporating critical debates about the nature and role of art in social practices, $D e$ donde son los cantantes emphasizes the potential of language to generate pleasure and promote the active participation of the reader in the creation of meaning.

1 That fleeting object of desire: Happening and art in action in Severo Sarduy's From Cuba with a Song

2 Ph. D. in Romance Languages and Literatures, Universidad de Washington in St. Louis. Profesora Asistente en Estudios hispánicos e italianos de la Universidad de Albany, Estados Unidos. Correo:maguilardornelles@albany.edu 
Palabras clave: Severo Sarduy, teatralidad, action painting, happening, lenguaje y placer
Keywords: Severo Sarduy, theatricality, action painting, happening, language and pleasure

La obra del escritor cubano Severo Sarduy (1937-1993) se arma fragmentariamente, como un conjunto de aparentes inconsistencias que invitan al lector a convertirse en copartícipe del acto estético. "Leer" a Sarduy se convierte en una exploración, un peregrinaje por textos múltiples y polifacéticos que se "arman" y "desarman" ante la expectativa gozosa del lector o espectador. Artista plástico, crítico de arte, ensayista, poeta, narrador y dramaturgo, Sarduy nos desconcierta y desafía al ofrecernos una obra que abandona las expectativas tradicionales de "lo legible" para incorporar el deseo y el placer. En sus novelas, Gestos (1963), De donde son los cantantes (1967), Cobra (1972), Maitreya (1978), Colibrí (1984) y Cocuyo (1990), se manifiesta el deseo de desvirtuar los límites, de celebrar la disolución de las fronteras entre contenido y forma, de imaginar gozosamente lo inaudito. Según Sarduy, la obra literaria desarrolla "su erotismo fundador" (1987: 298) cuando desatiende su intención comunicativa y se libera de lo que Roland Barthes llamó la "represión histórica" (1980a: 3) que la mantiene subordinada a las reglas del pensamiento racional. En otras palabras, Sarduy nos propone que aquello que le confiere clausura a la significación intentando dar cuenta de un referente es lo que le sustrae su potencialidad estética y su componente placentero.

En los ensayos en que Sarduy reflexiona sobre la obra de artistas plásticos de su tiempo se encuentran valiosas claves de su propia exploración estética. Por ejemplo, en "Cubes", publicado en Tel Quel en su número 32 , el escritor cubano sostiene que:

Si el arte de Larry Bell nos desorienta al principio es porque
de un modo irreversible y por su propia literalidad termina
con todos los prejuicios de trascendencia. En él, y a partir
de un lugar privilegiado para ello, es decir un cuerpo, una
escultura, se destruye la noción de arte como una referencia
a un algo que no es su propio físico: es precisamente el
soporte, el andamiaje, lo que constituye la obra (1987: 308).

Pocos meses después de la aparición de este artículo, Sarduy puso en práctica estos postulados al publicar la novela más experimental de su tiempo: De donde son los cantantes. Novela en la cual el plano de la escritura, como acertadamente ha planteado Ana María Barrenechea, se distancia hasta lo inverosímil de lo que sería su 
referente (1988: 518-9). Escrita en París y publicada en México en 1967, De donde son los cantantes desarticula las convenciones formales de la narrativa al poner en cuestión la operatividad de conceptos tales como personaje, trama, unidad narrativa y desenlace. Dicho desmontaje conceptual ofrece al lector la oportunidad de "actuar" como co-creador de la materia narrada. Esta novela también reorganiza el material narrativo articulando un diálogo creativo con las principales innovaciones de las artes visuales y escénicas de su tiempo. Susan Sontag, en su celebrado ensayo Against Interpretation, contemporáneo a la novela de Sarduy, nos alertaba sobre los peligros de una interpretación en busca de ese "otro texto" que desnudara el contenido de una obra de arte. Proclamaba Sontag la necesidad de una erótica del arte que reemplazara a la hermenéutica (2001:14). La exploración de las estrategias implementadas en De donde son los cantantes para eludir interpretaciones reduccionistas y potenciar el placer estético es el objetivo de este ensayo.

Gustavo Guerrero entendió el horizonte estético de Sarduy como una "creación en acto" (1987: 34). Siguiendo esta línea de análisis, me propongo explorar las estrategias retóricas utilizadas por Sarduy al narrativizar elementos que deberían permanecer ocultos al lector. $\mathrm{Al}$ enfrentarse con un texto que le exige entender la lectura como acción, ya que el pacto de lectura no se basa en la comprensión de un significado -siempre en fuga, siempre difuso-, sino en la experiencia de la materialidad del lenguaje, el lector activa en la novela su particular naturaleza de evento. Entiendo por "evento" un fenómeno que no es posible predecir y que es único y singular provocando un efecto de indeterminación que nos lleva a pensar la historicidad desde la eventualidad y la contingencia. Según Jacques Derrida "the event is also what comes, what happens" (2007: 443). La propuesta de Derrida es útil para mi análisis en tanto entiende al evento como ajeno a la ontología, ya que no es susceptible de ser inscrito ni siquiera como posibilidad antes de su advenimiento (Derrida, 2007; 2002:71-160). Es decir que la experiencia de lectura propiciada por la narrativa de Sarduy pone en crisis las expectativas del lector que se encuentra con un texto que lo invita a una lectura "en acción".

A partir de esta idea del texto sarduyano como evento estético me interesa discutir aquí algunos de los aspectos de su obra que manifiestan su deseo de ampliar los límites de "lo literario" a través de la incorporación crítica de las innovaciones desarrolladas en el campo de las artes plásticas y el happening en el periodo posterior a la Segunda Guerra Mundial. Me propongo, entonces, examinar las estrategias retóricas implementadas en De donde son los cantantes 
privilegiando aquellas que permiten señalar el diálogo entablado con la estética del action painting y del happening. Me interesa identificar algunos pasajes de la novela en que se propone una poética del arte en acción, postulándose como un artefacto que celebra lo efímero y defiende la búsqueda del placer estético como única "verdad" del lenguaje ${ }^{3}$. Al operar desde significantes que se multiplican en asociaciones y sugerencias, en esta novela el signo lingüístico asume su posición de generador de un intercambio estético en constante construcción y disolución. En ella, la música, el movimiento, la visualidad y la performance se amalgaman en una fiesta del lenguaje para dar cuenta de la tensión creativa entre la materialidad lingüística y la intención mimética. De este modo, se plantea un desafío a la capacidad del lector de hallar placer en un texto que le demanda abandonar la búsqueda de la significación. Esto me lleva, por último, a reflexionar sobre el valor de la práctica literaria de Sarduy en tanto discurso performativo que produce una paradójica relación de atracción y distanciamiento con el lector, cuya acción -la lectura- se resignifica también desde una conceptualización que celebra el placer de lo efímero, contingente y banal.

\section{Deseo, fascinación y lenguaje: mirar la literatura desde las artes visuales}

La intervención de Sarduy en el terreno de las artes visuales se remonta a su trabajo como crítico de arte en La Habana de los años cincuenta cuando colaboró en revistas como Ciclón, Carteles y Nueva Generación, y trabó amistad con intelectuales como José Rodríguez Feo, José Lezama Lima y Virgilio Piñera. De esa época son sus primeros textos narrativos, "El seguro" y "El torturador", escritos entre 1956 y 1959. Luego del triunfo de la Revolución Cubana (1959), Sarduy asumió el papel de crítico de artes plásticas de Lunes de Revolución. También colaboró con la Nueva Revista Cubana que editaba Cintio Vitier y realizó lecturas en el Palacio de Bellas Artes y el Teatro Nacional de los Trabajadores. En los textos de crítica de arte escritos en ese periodo se revela su posición frente al debate entre arte abstracto y arte figurativo. Por ejemplo, en el programa de Mantilla Expone, muestra artística realizada en 1957, y en el programa

3 Roland Barthes señaló que la estética de Sarduy apela al placer como la única "verdad" del lenguaje (1980b: 4). Retomo aquí, también, la fundamental propuesta de Adriana Méndez Ródenas, quien sostuvo que el "lenguaje neobarroco, basado en la carencia de centro significativo, produce la relación de erotismo entre palabra y deseo" (1978: 61). 
Loló 1953-1957, escrito para la exposición de la pintora Dolores Soldevilla, Sarduy manifiesta su entusiasmo por la pintura abstracta en detrimento de la estética mimética (González Echevarría, 1987: 23-26). Además, en los primeros meses del gobierno revolucionario, Sarduy publicó en Lunes de Revolución artículos en los que se oponía a que el arte figurativo se convirtiera en matriz rectora. En el artículo "Contra los críticos" (1959) se mostró contrario a que la oficialidad interviniera o determinara los parámetros de la creación del artista, debatiendo así los límites y alcances de un "arte revolucionario" (Véase Méndez Ródenas, 1983: 18).

En 1959 Sarduy se trasladó a París, y desde allí "pudo releer la tradición cubana con ojos nuevos" (González Echevarría, 1987: 39). El motivo de su viaje a Francia (realizar estudios de arte en la École du Louvre) se transformó en un nuevo proyecto y el escritor ingresó a la École Pratique des Hautes Etudes. Poco tiempo después Sarduy se vinculó al grupo Tel Quel y se ubicó en el epicentro del debate acerca del estatus del texto literario al relacionarse con intelectuales franceses como François Wahl y Roland Barthes. Sin duda, la mirada inquisitiva y la perspectiva lúdica le permitió a Sarduy acercarse al estructuralismo francés y a la herencia de Ferdinand de Saussure para articularlo a la estética barroca, que en Cuba se vinculaba a la obra de Alejo Carpentier y José Lezama Lima. Según Ester Pino Estivill, Sarduy partió de la concepción de Michel Foucault de la literatura como red y de la propuesta de Barthes del crítico como escritor para crear su propia gramática de la creación estética (2015: 169). Sin embargo, la poética de Sarduy no trata tan solo de alterar la forma en que se concibe la obra literaria en tanto sistema cerrado de referencia y ponerla en contacto con otras esferas de la expresión artística.

En la capital francesa aparecieron sus primeras obras narrativas en las que confluían la reflexión sobre el arte moderno y la incorporación de técnicas narrativas experimentales ${ }^{4}$. Según Sarduy, Gestos, su primera novela, fue concebida como pintura en acción (action painting) utilizando operaciones y métodos similares a los empleados por artistas del expresionismo abstracto como Jackson Pollock, Willem De Kooning y Franz Kline (Laddaga, 2007: 48). La crítica especializada ha señalado ya la utilización, en esta

4 Carolina Toledo sostiene que, en París, Sarduy siguió colaborando con revistas cubanas como Artes Plásticas y Lunes de Revolución, se formó en museología y realizó exhibiciones de pintura (2017: 57). Sobre la relación entre la obra de Sarduy y la plástica, véase Pérez, Severo Sarduy (2012) y Laddaga (2007). 
primera novela de Sarduy, de técnicas descriptivas de "cuadros" paisajísticos que desafían nociones espaciotemporales, asociadas a la experimentación en el arte moderno de nuevas técnicas que desafían la visibilidad ${ }^{5}$ Gestos, como la novelística posterior de Sarduy, se propone como una exploración de elementos que provocan el debilitamiento de los límites que definen forma y contenido, alertando así sobre nuestra capacidad de percibir y de imaginar el mundo. A través de la incorporación de un "lenguaje danzante", según ha propuesto Tatiana Alekseeva (2012: 9), en Gestos se deconstruye la novela realista ya que se amalgaman las tradiciones performativas del legado africano con la búsqueda estilística del neobarroco sarduyano.

La fascinación de Sarduy por la dimensión plástica del lenguaje y la construcción de figuras porosas capaces de disolverse en su entorno se convierten en De donde son los cantantes en una expresión lúdica y transgresora. Confluyen en la novela debates sobre la naturaleza del objeto artístico y una visión humorística que desarticula, desde la parodia y lo grotesco, las pretensiones de la literatura como discurso trascendente ${ }^{6}$. Además de contradecir la concepción dominante en los años sesenta del escritor comprometido y de la literatura puesta al servicio de ideologías homogeneizadoras, esta novela construye para sí una poética de lo efímero y de lo placentero a través de la exaltación de la materialidad del signo lingüístico ${ }^{7}$. A estos efectos, los personajes de De donde son los cantantes no representan a individuos ni responden a parámetros tales como unidad o coherencia, ya que son figuras que "están dotadas (y abusan) del poder de la metamorfosis" (1993: 235) ${ }^{8}$. En cuanto a la estructura, la novela está constituida por tres historias, enmarcadas por un

5 Sobre este particular, véase Ulloa (1985), Olmedo (2005), Méndez Ródenas (1983: 95-100), Pérez (2012), (2013) y González Echevarría (1987: 7). Gustavo Guerrero en su artículo "Sarduy o la religión del vacío" (1996), analiza la influencia de Kline en la obra del escritor cubano asociándola a una mística del vacío. Según Guerrero, fuera "cual fuere la última convicción del cubano, lo cierto es que, en un muy largo trecho de su vida y su obra, el vacío fue su más íntima verdad, su concepción del mundo y, ya es hora de decirlo, también su auténtica religión” (1996: 45).

6 Sobre el uso del choteo y la parodia carnavalesca para desmontar una identidad cubana homogénea, ver el relevante artículo de María Celina Bartolotto (2009). Sobre la novela como "incesante parodia" de todo relato, ver Sánchez Robayna, 1995: 7-9.

7 Pedro Férez Mora ha señalado acertadamente que "la poética de Severo Sarduy es, literalmente, pura materia" (2014: 15). La exploración de los cuerpos y de la materialidad de los elementos que se amalgaman en la obra de arte conducen en la poética de Sarduy a un exceso de signos, a un derroche de significantes nunca atados a significados precisos. 
prólogo, “Curriculum cubense", y por una "Nota”. Sin embargo, no hay una trama que responda a una progresión lineal o a una cronología en esta narración que comienza con la lluvia y termina con la nieve sobre La Habana.

Como bien ha señalado González Echevarría, desde su propio título De donde son los cantantes, que remite a un verso de la canción popular "Son de la loma", encierra la pregunta y la respuesta acerca de lo que "es Cuba sin nombrarla" (2003: 45). Además de la insistencia en las raíces multiétnicas de la identidad cubana, Sarduy elabora una narración en la que la simulación opera como vehículo de desmontaje de cualquier discurso que defienda una identidad estable o fija. Los personajes que aparecen en sus páginas son entidades que se muestran susceptibles de metamorfosearse alterando no solo su identidad, sino también transformando su naturaleza. Los personajes, Auxilio, Socorro, el General, Mortal Pérez, la Dolores Rondón -así como otras entidades narrativas como Yo, el Lector y G-, alertan al lector acerca de la condición contingente de toda construcción identitaria9. En tanto efecto de lectura, las transformaciones constantes de personajes, espacios y eventos operan como interrupciones que desconciertan y obligan a un ajuste de los parámetros de interpretación del texto.

En efecto, desde sus imágenes iniciales la novela enfatiza su propia artificialidad y su deseo de ubicar al lenguaje como problema en primer plano. Así comienza De donde son los cantantes:

Plumas, sí, deliciosas plumas de azufre, río de plumas arrastrando cabezas de mármol, plumas en la cabeza, sombrero de plumas, colibríes y frambuesas; desde él caen hasta el suelo los cabellos anaranjados de Auxilio, lisos, de nylon, enlazados con cintas rosadas y campanitas, desde él a los lados de la cara, de las caderas, de las botas de piel de cebra, hasta el asfalto la cascada albina. Y Auxilio rayada, pájaro indio detrás de la lluvia.

- ¡No puedo más! - chilla, y abre un hueco en las migas de pan.

- ¡Revienta! - es Socorro la que habla -. Si, revienta, aguanta, muérete, quéjate al estado, quéjate a los dioses, drop dead,

8 Myrna Solotorevsky ha señalado el funcionamiento de la metamorfosis como principio estructurador de la narración (1994: 187).

9 Sobre el personaje Dolores Rondón y su relación con la leyenda camagüeña, véase Sánchez (2003). 
cáete abierta en dos como una naranja, ahógate en cerveza, en frankfurter chucrute, jódete. Conviértete en polvo, en ceniza. Eso querías.

Auxilio aparta las mechas. Se asoma, quevediana:

- Seré ceniza, mas tendré sentido.

Polvo seré, más polvo enamorado.

Socorro - ¡Tu me casses les cothurnes! (en français, dans le texte). Calla. Yo tampoco puedo más. Sécate esa lágrima. Ten pudor. Ten compostura. Aguanta. Toma el vanity.

El espejito hace señales. Dirige el sol hasta el rascacielos de cristal al balcón del piso veinte sale una niña con otro espejo en la mano. Da saltitos y lo mueve buscando la llamada (1993: 91-92).

Este fragmento narra unos breves segundos de la conversación entre Auxilio y Socorro, sugiriendo, además de su situación de enamoramiento y tristeza, el desamparo de estos personajes en medio del "asfalto" y la "lluvia". Si bien, como ha señalado González Echevarría entre otros, las plumas aluden al mundo gay (1993: 91), este fragmento construye una imagen que, como los personajes, parece disolverse en la lluvia ${ }^{10}$. Además, el lenguaje se muestra insuficiente e incapaz de abarcar la experiencia de Auxilio y Socorro que desde el exceso de su disfraz y maquillaje recurren a la cita de los versos de Francisco de Quevedo y a diferentes códigos lingüísticos ${ }^{11}$. A pesar de recurrir a varias lenguas para expresar su deseo, no lo logran y necesitan recurrir al espejo para hacer señales. La novela comienza, así, como un llamado. Guiados por los nombres de los personajes, Auxilio y Socorro, podríamos decir que es un pedido de ayuda dirigido a los lectores.

La transformación del espejo en artefacto de comunicación refiere no solo al espacio hostil en que se encuentran los personajes Auxilio y Socorro, sino que también da cuenta de cierta fluidez de toda materialidad $^{12}$. El rascacielos de cristal, la duplicación del espejo, las lágrimas y la lluvia nos obligan a resemantizar la enunciación a través de imágenes inestables para las cuales no hay referentes más allá de la sensación de pérdida y vacío. El espacio se nutre de connotaciones asociadas a la fluidez y a la transparencia al mismo tiempo que la enunciación se aleja de referentes precisos. El intenso

10 La figura del travesti en la poética del Sarduy epitomiza la búsqueda incesante de una imagen abstracta que no existe sino en la performance (1987: 90-1). Al respecto véase Birkenmaier (2002), Sifuentes-Jáuregui (2002) y Pérez (2013).

11 Auxilio cita el último verso del soneto de Quevedo "Amor constante más allá de la muerte": "polvo serán, mas polvo enamorado" (1981: 255-256). 
cromatismo de la escena, que comienza con la imagen de plumas de color amarillo, propio del azufre, y se prolonga en los tonos anaranjados, rosados, grises y blancos, convierte al primer escenario urbano con el que se encuentra el lector en una festiva decoración que parece querer contradecir la tristeza que embarga a los personajes. La novela presenta una cuidadosa selección de estímulos visuales que fascinan por su proliferación al mismo tiempo que despiertan la imaginación. Así, la verbalización de la expresión "muérete, quéjate al estado" se potencia en medio de una abrumadora fiesta de los sentidos que intensifica la situación de desamparo y precariedad de los personajes ${ }^{13}$.

Además de enfrentarnos a la "enigmática figuración de la otredad" (Guerrero, 2007: 20), este comienzo in media res subraya la materialidad emancipada del lenguaje. Por una parte, el encadenamiento de imágenes nos recuerda que el barroco es "una decorazione que se ha emancipado de todo servicio como tal, que ha dejado de ser medio y se ha convertido ella misma en fin" (Echeverría, 2000: 45). Por otra parte, la figura de Auxilio vehiculiza enlaces metafóricos de elementos que se encuentran distantes en el texto, pero que remiten a una misma referencia pictórica. Así, las cualidades de Auxilio, "rayada" y "pájaro", se incorporan a la mención de las "botas de piel de cebra" (1993: 91), a su calificación como "Vasarélica" (1993: 92) y a la imagen de "una cabra que se quita sus rayas negras para hacer con ellas un Vasarely" (1993: 101). La perspectiva estética del artista húngaro, Víctor Vasarely (19081997), ingresa así a la narración para contribuir en la creación de un ambiente en el cual la sorpresa visual y el engaño perceptivo se potencian con el encadenamiento de imágenes desconcertantes ${ }^{14}$. La recurrencia de los elementos cebra-rayas-Vasarely, potenciada por la cita intertextual, revindica al artefacto artístico como generador de sensaciones inesperadas que celebran su condición de artificialidad. La entidad narrativa conocida como "personaje", opera, entonces, como una síntesis de sensaciones en las cuales lo pictórico y lo alegórico confluyen en una amalgama no carente de conflicto.

12 Para un análisis de la presencia de espejos y su relación con un cuestionamiento a la identidad cubana, véase Batolotto (2009: 21-2).

13 Andrés Sánchez Robayna sugiere que Sarduy desarrolló “una de las más radicales y comprometidas formulaciones de un muy moderno proyecto de reinvención de la fiesta como espacio de relación entre lenguaje y mundo" (1995: 1).

14 Víctor Vasarely, líder del Op Art, desarrolló su primer trabajo mayor Zebra, a la cual alude el texto de Sarduy, a principios de 1930. Sobre la obra de Vasarely, véase Spies (1969: 5-19). 
Sin embargo, esta recurrente imagen apunta también a una serie de asociaciones que convocan intertextualmente a la obra de Franz Kline (1910-1962) y sus líneas negras sobre fondos blancos que recuerdan la caligrafía oriental ${ }^{15}$. Como Sarduy explicara en la entrevista concedida a Emir Rodríguez Monegal para Mundo Nuevo en 1969, la iconografía expresionista plantea un cierto "tipo de deformación, de distorsión de la linearidad verbal, de la frase que podríamos llamar figurativa" (1970: 318). Es así como la iconografía expresionista y la pintura en acción, le permiten al escritor cubano plantearse una "escritura gestual" o arte en acción. Su fascinación por la estética del action painting no solo se encontrará, como él mismo lo confesó, en su novela Gestos, sino que impregna una búsqueda estética definida en los siguientes términos: "formular teóricamente una escritura cuyo sentido sería muy neto: inscribir el mayor número de direcciones posibles, dialogar con el mayor número de texturas posibles" (Sarduy, cit.por Rodríguez Monegal, 1970: 323).

En 1965 Sarduy publicó en Tel Quel una serie de poemas titulados "Páginas en blanco (cuadros de Flanz Kline)", en los que se revela esta búsqueda ${ }^{16}$. Dice un fragmento del poema:

\section{VI. black and white}

La raya negra y el battello, el monte siamo tutti,

el barco blanco sobre el agua blanca

y la fijeza

de los pájaros sobre la Salute (Sarduy, 1999: 193).

15 Pedro Férez Mora sostiene que "la invocación de lo Imaginario que efectúan la pintura de Rothko y Kline y, con ellas la poesía de Sarduy, aspira en última instancia a poetizar, a liberar, a metaforizar, la subjetividad -la vida- del hombre" (2014: 31). Férez Mora plantea un cuidadoso estudio del diálogo entablado Sarduy desde su obra poética de con la obra de Mark Rothko, Franz Kline y Antoni Tàpies (2014: 159192). Silvana Santucci y Bruno Grossi (2018) también señalan la correspondencia con la obra de Rothko, proponiendo un cuidadoso análisis de los vínculos entre teorización estructuralista, estética neobarroca y la dimensión política del uso de los colores en la obra de Sarduy.

16 Andrés Sánchez Robayna también ha estudiado las referencias a obra de Kline en los "Poemas bizantinos" (1961) de Sarduy. Según Sánchez Robayna, "lo que Sarduy quería decir con la expresión action writing: [era] un cierto tipo de improvisación sintáctica, de frase escuchada, más que construida, y que tiene mucho que ver con el fraseo y las improvisaciones del jazz" (2008: 52). 
La insistencia en el color blanco, que se transformará en nieve en el desenlace de De donde son los cantantes, recuerda el lienzo y la página en blanco en ausencia del trazo, imagen o figura. Andrés Sánchez Robayna encuentra en estos poemas una reflexión sobre la movilidad y la inmovilidad, sobre "el movimiento sin tiempo" (1995: 5). Sin embargo, la ausencia de movimiento, patente en el poema desde la "fijeza", se desmonta y cuestiona por la aparición del trazo, de la palabra. El blanco como ausencia se presenta como amenaza, pero también como unificador de las múltiples potencialidades de la expresión artística que recuerdan las pinturas blancas de Robert Rauschenberg (1925-2008). Las White Paintings (1951) son cinco obras que consisten en un número diferente de paneles pintados completamente de blanco, a las que Rauschenberg consideraba como un concepto y un espacio para la imaginación, permitiendo que otros artistas trabajaran sobre ellas. En el caso del poema de Sarduy, el blanco anuncia un deseo que se completa con la presencia del negro: los trazos movedizos de "los pájaros sobre la Salute".

En otro poema de la serie, el escritor cubano vincula el silencio a la otredad, a la palabra que se revela más allá del yo diciendo:

\section{I wax wing.}

No hay silencio

sino

cuando el Otro

habla

(Blanco no:

colores que se escapan

por los bordes).

Ahora

que el poema está escrito.

La página vacía (Sarduy, 1999: 191).

El blanco remite, así, a una fuga y a un vaciamiento que antecede a la escritura convirtiendo la palabra en objeto de deseo. La fuga de colores presagia la búsqueda de la palabra poética, del lenguaje estético, que es ante todo la búsqueda de la voz del otro. La escritura no completa la página, sino que la vacía de potencialidad, la convierte en enunciación permeable a la interpretación.

Además de la relación con la obra de Kline que el autor cubano hizo explícita, su narrativa traza líneas de reflexión cercana a las preocupaciones estéticas de Jackson Pollock (1912-1956). La obra de Pollock, al igual que la de Kline, descubre una de las facetas más 
atractivas, para Sarduy, del arte "gestual" y la consiguiente ruptura con el concepto mimético del arte. Pollock utilizó la técnica del dripping o goteo, que consiste en salpicar de forma espontánea y enérgica la pintura encima de un lienzo. Al hacerlo, demostró que concebía la pintura y el lienzo como materias vivas que al fluir en pequeños hilos, manchas, puntos y gotas coaguladas recuerdan el movimiento que les dio origen. El ritmo y la dinámica de movimientos sugeridos por el colorido de las manchas o gotas convierten el espacio en acción y enfatizan que lo relevante no es el contenido o la idea, sino el proceso, el acto mismo de pintar. En oposición al artista intelectual que reflexiona y expresa una realidad referencial, la pintura de Pollock transforma el arte en acción visible más allá de los límites del soporte. En Shimmering Subtance (1946) se aprecia a través de la gama de colores -blanco, amarillo y rojo - que los gestos son libres pero no arbitrarios o casuales; en Autumn Rhythm (1950), la última de sus monumentales pinturas utilizando la técnica del dripping, el lienzo sin imprimar y salpicado de manchas se constituye a través de la repetición del derrame de pintura; en Sleeping Effort (1953) las pinceladas visibles son rastros de la serie de "actos" realizados por el pintor. Al admirar su pintura, el espectador es invitado a recuperar el "gesto" y la movilidad del artista que, al hacer visible la técnica y método de trabajo, invita a imaginar el proceso de realización de la pieza y muestra el andamiaje de una pintura que solo se completa frente al "acto" de ser explorada. Así, la pintura en acción de Pollock es una apuesta por la teatralidad del acto estético.

\section{Teatralidad y arte en acción: la novela como happening}

La teatralidad ha sido considerada por los investigadores como inseparable de la obra de Sarduy (González Echevarría) y como componente fundamental de la estética neobarroca (Quesada, 2009: 199). Sin duda, las obras de John Osborne, Bertolt Brecht, Samuel Beckett y Antonin Artaud, que en la década de los años cincuenta introdujeron cambios a la estructura y expectativas del género teatral, fueron particularmente atractivas para la estética de Sarduy (véase Esslin, 1961 y Prietsman, 1992: 118-9). Sin embargo, la teatralidad es para Sarduy un "modelo de interpretación semiótica" (Guerrero, 2007: 15). Más aún, la teatralidad como herramienta interpretativa aparece en De donde son los cantantes atravesada por la ruptura con la pretensión de unidad y permanencia, enfatizando el aspecto contingente de toda construcción. Surgida como enunciación oral, ya que fue originalmente un programa radial titulado "Dolores Rondón" (1965), De donde son los cantantes encarna la escritura como contingencia y artificialidad, como arte en acción provocando 
la explosión de imágenes que antagonizan con la organización lógica racional. Esto se observa, por ejemplo, cuando la voz narrativa dice:

En menos de lo que un mono se rasca un ojo se oye el grito de “iMetamorfosis!” en Si Bemol, y acto seguido aparecen las Dos montadas en sendas Vespas de carrera, a toda máquina, y armadas de ametralladoras Thompsom, cuchillos bífidos, jabalinas, lanzallamas, pistolas pum-pum, granadas de mano y bombas lacrimógenas. [...] Lo que sí es ya asombroso es que cada Una está provista de tres cabezas y siete brazos. iHay que ver el artefacto de aluminio tetradecápodo y hexacéfalo! (1993: 117).

La ruptura con la lógica numérica ironiza acerca de las pretensiones de unicidad, así como también niega toda idea de secuencia, ya que cada imagen se manifiesta como un evento, impredecible y fortuito. El texto agudiza el efecto de ostranenie o desfamiliarización a través del exceso de imágenes, la desmesura de personajes en constante transformación y el encadenamiento de eventos impredecibles. Esta ostranenie proyecta la visión de una realidad textual como "sistema móvil de relaciones" (Sarduy, cit. en Rodríguez Monegal, 1970: 321) que exige la acción de un lector capaz no sólo de interpretar una enunciación múltiple y simultánea, sino también de disfrutar de la sensación paroxística de una búsqueda incesante.

Alberto Moreiras ha señalado acertadamente que la "última rotunda metamorfosis de la novela" (1991: 99) es la "Nota" final, a través de la cual Sarduy desdobla la voz narrativa para crear un simulacro de resumen-explicación que parodia la intención de la crítica de fijar una interpretación que devele las intenciones del autor. En un texto en el que cada elemento se encuentra con su doble, o con múltiples versiones de sí mismo, esta "Nota" es una de las tres variantes de "notas" que aparecen en la novela. Las notas al pie de página, además de las cuatro "notas" insertadas en la estructura del texto, permiten el desdoblamiento de la voz narrativa en tres entidades que Catalina Quesada relaciona a la función de editor, narrador y autor (2009: 204-5). La "Nota" final es la enunciación de una subjetividad que se autoconstruye con autoridad para fijar la "correcta" interpretación del texto. Sin embargo, más allá de la intensión paródica y la perspectiva metanarrativa de este texto que busca reflexionar sobre su propia naturaleza de artificio, me interesa resaltar su énfasis en la literatura como palimpsesto, amalgama de textualidades diversas y como reescritura de un texto popular que la antecede. La "Nota" final confiesa: "Este relato -sonoridad, acción: teatro- elucida una décima grabada en una lápida del cementerio de Camagüey" (1993: 236). 
Parte de la clave interpretativa que me interesa proponer reside precisamente en la tríada "sonoridad, acción: teatro". Celebrar la literatura como la confluencia de la sensualidad sonora del lenguaje y la escritura como acción y como performance altera la concepción del tiempo como progresión lineal, negándose a construirse como relato fundador de una teleología. De donde son los cantantes es "un texto que burla a sus exégetas represores, que no admite la captura bajo la identidad modélica ni la simulada" (Moreiras, 1991: 95), pero también es un texto que se exhibe como escritura en acción concebido para potenciar el efímero placer de la enunciación literaria.

Sin duda, la obra de Sarduy se inscribe dentro del movimiento contracultural de los años sesenta y setenta que intentó, a través del arte, plantear alternativas al consumismo y la violencia de la sociedad capitalista occidenta ${ }^{17}$. El arte de ese periodo se caracterizó por presentar una reformulación del concepto de obra por el uso de "objetos encontrados" y collage, y una erosión de la condición del artista como individualidad, haciendo hincapié en la colaboración grupal y la desaparición de la distinción entre autor y público, ya sea en teatro, lecturas de poesía o happenings (Moore-Gilbert y Seed, 1992: 6). El happening, como su propio nombre lo pone al descubierto, propone una intervención en el espacio al crear un "evento" artístico efímero que se desarrolla contando con la participación de los presentes. La primera manifestación del happening, Theater piece №1 (1952), fue descripta por su autor John Cage (1912-1992), como un evento teatral sin trama. Fue Allan Kaprow (1927-2007), autor de Assemblage environments happenings (1966), Untitled essays and other works (1967), quien usó por primera vez la palabra happening cuando en 1957 intentaba describir las improvisaciones que se presentaron en la granja de George Segal durante un Picnic artístico. Kaprow inició con su obra 18 happenings in 6 parts (1959) una serie de actividades vinculadas a la performance y la intervención que requerían una activa participación del público. El happening de Kaprow, respondiendo a las reformulaciones utópicas vinculadas a los proyectos marxistas del momento, abogaba por un borramiento de las fronteras entre arte y vida y atacaba la mercantilización de la cultura.

Al igual que el happening, la obra de Sarduy integra la plástica, la música y la poesía en el espacio textual que potencia los múltiples

17 Acerca de la contracultura entendida como un grupo de expresiones alternativas a la cultura hegemónica, ver Roszak (1995). 
niveles de significación del lenguaje. El autor refiere a su diálogo con esta estética en "El estampido de la vacuidad" diciendo:

Marcel Duchamp, John Cage, Octavio Paz: se trata de imitar a la naturaleza. Pero, por supuesto, no en su apariencia -proyecto del realismo ingenuo-, sino en su funcionamiento: utilizar el caos, convocar el azar, insistir en lo imperceptible, privilegiar lo inacabado. Alternar lo fuerte, continuo y viril, con lo interrumpido y femenino. Teatralizar la unidad de todos los fenómenos.

Olvidar el resto. Pero no hay resto (1999: 107).

La mención a la obra de John Cage no es aleatoria. Por el contrario, referir a este artista creador de Theater piece le permite a Sarduy convocar toda una red de relaciones que enfatizan su propia concepción del texto como evento, privilegiando el efímero encuentro en que el lector hace posible la realización del texto como espacio de interacción y colaboración.

Una de las primeras actuaciones multimedia colaborativas de Cage fue Theatre Piece No. 1, pieza conocida también como "The Event". Este happening inspirado en El teatro y su doble, de Antonin Artaud, incluyó lecturas de poesía, música, danza, proyecciones fotográficas, películas y cuatro paneles de las pinturas blancas de Rauschenberg suspendidas del techo. Durante los años siguientes, Cage se concentró en desarrollar una estética basada en el concepto de "indeterminación", que él concebía como actualización radical del azar. Interesado en obras artísticas que implicaban una acción en el presente y el azar como principio organizador de la pieza, Cage intervino en la escena artística internacional a partir de una estética en la que el yo del creador se ausenta o distancia de la obra. Kaprow, alumno de Cage, trasladó las investigaciones de su maestro hacia un enfoque, según sus palabras, más "espontáneo" y más "placentero" del happening al "comenzar a imaginar las cosas, comenzar a escribir los papeles de los diversos integrantes del evento a medida que uno va progresando, hasta el momento en que decide parar" (Joseph, 2009: 111). A través de las nociones de azar, anarquía y "acciones experimentales" como estrategias para operar desde lo imprevisto, las indagaciones estéticas de Cage y Kaprow incorporan el legado del action painting y ponen en cuestión la noción de autoridad sustituyéndola por la búsqueda de la impersonalidad e indeterminación ${ }^{18}$. Así, improvisación, espontaneidad y azar se conjugan para dar lugar a piezas que exploran el proceso, la acción, mediante la cual múltiples artistas o intérpretes interpelan simultáneamente a su audiencia. 
Del mismo modo que el happening, en la narrativa de Sarduy el azar aparenta regir las relaciones entre los diferentes elementos constitutivos de la trama. Más aún, la novela se presenta como un evento, al mismo tiempo que los personajes escenifican eventos, planteando así un borramiento de los límites entre el plano de la historia y el plano del discurso. Por ejemplo, Auxilio y Socorro intervienen en un self-service creando un espectáculo en el que interpelan a su entorno. Así dice el texto:

Todo el mundo las mira. Se saben acusadas. [...]

-Tengo una idea.

Abre una caja redonda forrada en piel de cocodrilo que trae colgada a la espalda con una cadenita plateada, como una cantimplora, y contándolas, saca cincuenta fotos de colores. Desecha dos, amarillentas, le entrega a Socorro un close-up en blanco y negro, y con las otras cuarenta y siete se va al extremo del comedor. Desde allí, mesa por mesa, las va repartiendo. A cada entrega sonríe, se da un peinazo, se presenta al destinatario con una reverencia y renueva su asombro con la descripción minuciosa de la foto. Socorro la sigue a unos pasos, añadiendo adverbios a los adjetivos, genuflexiones a las reverencias, refrescando el aire con su abanico de plumas de avestruz, rociándolo con ungüentos. A una señal de Auxilio, Socorro adjunta medallitas de la Caridad del Cobre y bombones (Sarduy, 1993: 98).

Auxilio transforma la relación con su entorno al intervenir en el espacio e implicar a los presentes en un evento que recupera su memoria personal a través de las fotografías. Sin embargo, no se trata de una mera exhibición de fotografías, sino de habitar el espacio para resignificarlo a través de una performance en la que el público, que al inicio las observaba, es forzado a intervenir y salir de su "asombro". Se trata, también, de un evento en el que a las múltiples variantes de la imagen fotográfica se suman un texto -las "explicaciones"- que se mantiene vedado al lector y la dinámica de desplazamientos de Auxilio y Socorro. La voz narrativa no interviene para interpretar el evento, sino que actúa a modo de acotación. Esta ausencia de intervención de la voz narrativa es la que provoca el desconcierto del lector al que se le informa del evento sin recuperar las elocuciones de los personajes.

18 Sobre la exploración del azar en la obra de Cage y la incorporación crítica por parte de Kaprow, véase Joseph (2009: 210-233). 
En esta escena el espacio es resemantizado para hacer circular el imaginario y la memoria. Además, los personajes se niegan a ser objetos de la mirada y se transforman en sujetos de una enunciación que rompe con las expectativas de lo cotidiano. A través de interrumpir con su intervención en el espacio, los personajes logran transformarlo en experiencia estética por medio de la fotografía, los paratextos y la performance. Este happening desarrollado por Auxilio y Socorro, además de incluir a los espectadores en su exhibición de fotografía y sacarlos de la masificación y el anonimato de la vida urbana, permite a los personajes inscribirse como agentes de un evento que enfatiza su condición de impredecible y singular. Dando cuenta de la espontaneidad de este evento radicado en el presente, uno de los personajes dice: "-No dejamos una mala impresión (1993: 99)", a lo que otro responde: “- Quizás. Pero vámonos antes de que se arrepientan (1993: 99)”. Este habitar el espacio como exploración estética se concibe en la novela desde lo efímero, lo transitorio y lo performativo.

Si bien la reproducción fotográfica introduce la idea del objeto artístico como revelador de una materialidad que se basa en la alteración del objeto que intenta representar, también la reescritura de varias versiones de la misma escena en la novela enfatiza la arbitrariedad del signo y la imposibilidad de una interpretación que no sea transitoria. Así, luego que los dos personajes dejan el selfservice el lector se encuentra con una "Nota" en la que un editor o compilador indeterminado interviene para describir en forma de acotación el espacio en el que se produjo el happening de Auxilio y Socorro. Esto se prolonga en "Una nueva versión de los hechos: parca y general" (1993: 100) con la que se cierra el "Curriculum cubense". De esta manera, la novela se presenta como una serie de eventos o intervenciones narrativas que rompen con la lectura tradicional, proponiendo la coexistencia de múltiples temporalidades. De donde son los cantantes se construye, así, como una serie de actos de enunciación, una multiplicidad de actores produciendo discursos que antagonizan entre sí, sin que ninguno de los narradores o entidades narrativas intente una síntesis del material.

En "Happenings: An Art of Radical Juxtaposition" (1962), Susan Sontag intentó describir el happening, en tanto género de espectáculo y experimentación artística. Sus observaciones se desarrollan en torno al surgimiento de lo que considera un nuevo género artístico durante los años de su mayor eclosión. Particularmente, llamó la atención de Sontag la imposibilidad de definir o categorizar esta estética, ya que ninguna afirmación sobre lo que es un happening 
en cuanto género sería aceptable para todos los artistas que los realizaban (2013: 249). El aspecto de la estética del happening que más sorprende a Sontag es el trato dado a los espectadores, ya que no se respeta el deseo del público de "ver" la obra. De hecho, el público puede sentirse frustrado, ya que el happening puede ser representado en semioscuridad o en diferentes habitaciones a un mismo tiempo (Sontag, 2013: 250). Por ejemplo, en A Spring Happening (1961), de Kaprow, el público fue introducido en una caja que simulaba un vagón de ganado teniendo que seguir el espectáculo a través de mirillas. Al final del happening los muros fueron derrumbados y el público fue expulsado por una excavadora. Lo que Sontag no parece percibir es la apuesta por un arte de lo efímero. Así, lo que esta crítica lee como "abusive involvement of the audience" (Sontag, 2013: 250) es, en realidad, una estética que busca romper con la concepción tradicional del tiempo como progresión. Lo que bien atestigua el texto de Sontag es que los happenings juegan siempre en tiempo presente (2013: 250) convirtiendo la experiencia estética en la confirmación de la ruptura con la historia como metarrelato.

Sontag acierta al atestiguar el rompimiento del happening con la concepción del arte como artefacto museístico y el borramiento de nociones tales como decorado, personaje o trama. Considerado por algunos como "collages animados" o "trompe l"oeil vivificados", el happening se manifiesta cercano a los assemblages, en los que se fundían la escultura, el collage y la pintura utilizando en su mayoría materiales descartados o desechados (Sontag, 2013: 253). Lo que hace el happening es sumergir o internar al espectador en una acción que, si bien se desarrolla frente a sus ojos, no es predecible, ya que no sigue una trama ni una secuencia cronológica. La ausencia de escenarios, actores y texto dramático se sustituye por una serie de actos que incluyen la exposición de pinturas, música y diferentes formas de performance, para crear un especial efecto de confusión que borra los contornos entre espectador, actor y autor. Del mismo modo, De donde son los cantantes insiste en hacer que el lector no reciba el texto como productor de mensajes, sino que propone al lector como agente productor situado en ese espacio liminar que es la novela. Tanto los lectores de la narrativa de Sarduy como los espectadores de los happenings son expuestos a la experiencia de verse envueltos en un arte en acción que demanda su constante intervención.

Plantear la novela como arte en acción la convierte en instrumento de ruptura con la temporalidad entendida como teleología, ya que no se estructura siguiendo pautas de causa y efecto o progresión lineal. 
En este sentido, De donde son los cantantes establece un tiempo abierto, y al hacerlo contradice la posibilidad de promover discursos basados en construcciones de sentido universalizantes. Violentar el deseo de alcanzar un significado apunta no sólo a señalar la vacuidad del signo como promesa de unidad y orden, sino que también intenta provocar el deseo por la multiplicidad cambiante y polisémica que el lenguaje encarna. Así tararea uno de los personajes:

El ser de los pájaros no es el timbre del trino, sino las plumas cayendo a cada muda. Blancas, son otro pájaro de nieve, la firma del primero; rojas, pez que se vuelve mariposa si lo atacan. Otro cuando muda, despista dejando ojillos de culebra entre las viejas plumas: dota de mirada a su impostura; su júbilo es clavarse en el aire frente a su doble ciego, enfrentar a los tigres el apócrifo. ¡Oh ardientes! ¡Oh feroces!

¡Oh, dulces pájaros! (1993: 131).

Este fragmento me interesa porque presenta un ejemplo de cómo el lector se ve envuelto por un texto rico en sensaciones. Es notorio que mediante el encadenamiento de fonemas oclusivos y sonoros $(/ \mathrm{p} /$, $/ \mathrm{t} / \mathrm{s} / \mathrm{b} / \mathrm{y} / \mathrm{d} / \mathrm{J}$ y su alternancia con fonemas fricativos y vibrantes $(/ \mathrm{s} /, / \mathrm{r} / \mathrm{)}$ el texto enfatiza la sensualidad de un lenguaje que recupera la disonancia y el sin sentido. Se trata, también, de un lenguaje que no surge a partir de subjetividades que lo enuncian, sino que es el lenguaje el que da origen a las subjetividades (Montero, 1988: 19). Son las plumas, el decorado, el artificio lo que el texto destaca como fundamental para el "ser". Son las plumas, también, que en su movimiento de caída constante revelan la condición efímera, transitoria y contingente de toda enunciación.

\section{Fugacidad y escritura: a modo de reflexión final}

El happening se diferencia de otras manifestaciones artísticas por su apelación a condiciones creativas que incorporan lo imprevisible, lo que no puede ser predeterminado ni controlado por la autoridad de un autor. El happening es una irrupción estética en un espacio imprevisto o no preparado para ese fin y cuya finalidad, trama, temática y duración permanecen desconocidas hasta su propio advenimiento. Estos eventos artísticos comparten con De donde son los cantantes varias características, de las cuales las más relevantes son la destrucción de la unidad tradicional de la obra literaria, la intención de definir una autoría múltiple negándole preeminencia a la autoridad del autor y el destaque de la performance como espacio de interacción entre el receptor y la obra artística. Al 
diferir el encuentro de una temática o trama la novela desvirtúa la autoridad del autor, aunque no puede disociarse del nombre que firma la novela, Severo Sarduy (Montero: 1988: 89). Las múltiples subjetividades que se proyectan como "autores" en el texto no son reconfiguraciones intradiegéticas del autor, sino que se trata de entidades narrativas, que como en el happening solo existen en tanto acto, en tanto enunciación. Además de las intervenciones a través de las "notas" que se multiplican en la novela, el autor interviene para dialogar con los personajes. Aquí un ejemplo:
Socorro - Yo lo que quiero es que acaben de sacar a Auxilio de este enredo.
Yo - Ya saldrá de él. Ya volverá a casa, modosa, presumida, casta.
Socorro - ¡Oigan eso! ¡Tres adjetivos de un golpe! En mi tiempo no era así. A dónde va la joven literatura...
Yo - Sí, querida, tres adjetivos seguidos, pero muy bien puestos. Así es que traga y cállate.
Socorro - Yo no tengo sentido de la digresión, así es que rápido: ¿qué pasó con mi amiga? (1993: 101).

Los personajes funcionan como acumulación de enunciaciones que pueden ser asociadas a funciones narrativas, tales como narrador, autor o personaje. Más aún, los personajes se reconocen tan solo por un nombre, pronombre (Yo), o por una letra (G) en una proliferación inaudita que destruye la ilusión de una subjetividad enunciadora unívoca y estable. El lector también se incorpora al texto, como lo muestra el siguiente fragmento:

Yo -Eso dice él. Lo cierto es que la Generala...

El Lector (cada vez más hipotético) de estas páginas Bueno, póngase de acuerdo: una versión o la otra. Lo que yo quiero son hechos. Sí hechos, acción, desarrollo, mensaje, en suma. ¡Mensaje lírico! (1993: 132).

La impaciencia que atrapa a los personajes y al Lector en busca de aclaraciones y de acción no tiene paralelo en el "Yo" que se define por ser el que produce el discurso. Al ser juzgada y examinada en múltiples ocasiones, la autoridad del autor intradiegético se muestra limitada por su incapacidad de controlar el texto y por su contingencia.

En el periodo en que los autores del Boom latinoamericano ensayaban la incorporación de novedosas estrategias narrativas, Sarduy se atreve a negar el concepto de literatura como discurso trascendente, portador de un "mensaje" que debe ser decodificado ${ }^{19}$. Para el escritor cubano no hay más que la materialidad sonora y plástica 
del lenguaje que construye y deconstruye la única "realidad" posible. La novela es, como ha señalado Oscar Montero, una exploración de las formas en que la ficción latinoamericana incorpora y reescribe la cultura (1988: 18). Más aún, De donde son los cantantes, en tanto ficción neobarroca, revindica la "marca de una diferencia americana que se resiste a la perfección de la esfera, y que incluso rebate la universalidad de su valor estético reivindicando en su lugar la singularidad y la contingencia" (Moraña, 2010: 54). La novela ejemplifica, así, el tenso diálogo en el que la producción cultural latinoamericana se apropia, distorsiona y multiplica los elementos heterogéneos de la modernidad, revalorizando elementos excluidos y alentando proyectos alternativos. El proyecto estético de Sarduy tiene implicaciones que van más allá de la literatura y las artes visuales proponiendo una reconceptualización del hecho estético como generador de deseo cuyo objeto, siempre en fuga, posterga y, por tanto, intensifica el placer del encuentro.

Si el happening epitomiza diversos tipos de resistencia ante el poder ilusorio de la clausura crítica (Rodenbeck, 2011: 9), la narrativa de Sarduy elabora un gesto contracultural proponiendo una estética del arte en acción. La novela pone la estética del action painting y del happening al servicio de una escritura asociada a prácticas corporales y a la teatralidad. Además, al desvincular la obra de arte de la conceptualización que prioriza el contenido, la narrativa de Sarduy se acerca al happening como evento que elude al mercado de circulación de bienes culturales dotados de un valor de uso. Es así como Sarduy concibe y ejecuta una literatura que subraya la contingencia de toda significación, de todo efímero encuentro entre el artefacto estético y su receptor. Celebrando el erotismo del lenguaje, Sarduy trabaja con la palabra desde su potencialidad, desde su capacidad para crear múltiples asociaciones que antagonicen con construcciones esencialistas. Esta es la única utopía a la que el escritor cubano parece adscribirse para demandarle a la literatura que "constituya artefactos destinados a la inducción de un cierto trance, de una salida de sí que se realice en la delicia" (Laddaga, 2007: $50)$. Es a partir de esta demanda que De donde son los cantantes se constituye como arte en acción.

En suma, Sarduy concibió la escritura como parte de una vasta red de interferencias y diálogos, en la cual confluyen las artes plásticas,

19 Sobre la relación entre el Boom y la obra de Sarduy, véase González Echevarría, La ruta (1987: 7-99) y "Sarduy, the Boom, and the Post-Boom" (1987). 
la filosofía, las religiones orientales y la búsqueda incesante por la palabra, ese inaprensible objeto de deseo. Es justamente en la capacidad generadora de placer y de deseo del lenguaje que se sitúa su narrativa. Sin embargo, no creo que se trate del "placer por el placer", como ha sido propuesto por Pedro Férez Mora (2014: 25). Se trata, en cambio, de una política del placer basada en una exploración minuciosa y reflexiva del barroco americano y un trabajo sofisticado y preciosista sobre la materialidad del lenguaje. La escritura es concebida como acción, movimiento, sonoridad, pero también como imagen, como representación escénica, como evento que interviene en la imaginación y fascina a su receptor, aun colocándolo en la dimensión inhóspita de una significación siempre en fuga. El lector se encuentra con un texto que no teme abrumarlo con el exceso de palabras, sino que despliega versiones múltiples de eventos y entidades para darle la oportunidad de reformular su propia acción interpretativa. Más aún, el texto reasigna al lector un espacio operacional desde el que reconfigurar su posición transitoria y contingente en tanto consumidor de un objeto artístico. La ilusión de poder, de autoridad discursiva, es desplazada desde el autor o entidad que organiza la emisión del texto, al lector, cuya realización de una lectura en acción parecer ser el objetivo de la máquina generadora de placer de Sarduy. La suya es una literatura que plantea un método de lectura que requiere el descubrimiento de un palimpsesto de estéticas aparentemente disímiles que develan que la única verdad del arte es su condición de artificio. Es también el descubrimiento de una poética del placer, en la cual "el deseo se desplaza, deambula detrás de su objeto y, pasado el momento de la saciedad, de nuevo lo solicita" (Sarduy, 1999: 245). Es, sin duda, la experiencia del placer del lenguaje que torna el inaprensible evento en perdurable efecto de lectura.

\section{Bibliografía}

Alekseeva, T. (2012). Lenguaje danzante: Las coreografías afrocubanas del neobarroco en Gestos de Severo Sarduy. AfroHispanic Review, 31(1): 9-28.

Barrenechea, A. M. (1988). Severo Sarduy o la aventura textual. En Cedomil Goic. (Ed.), Historia y crítica de la literatura hispanoamericana. III Época contemporánea (pp. 517-23). Madrid: Crítica.

Barthes, R. (1980a). El placer del texto. México: Siglo XXI. 
Barthes, R. (1980b). La faz barroca, Introducción. En Severo Sarduy. De donde son los cantantes, (pp. 3-6). Barcelona: Seix Barral.

Bartolotto, M. C. (2009). Fake for its Own Sake: a Staged Performance of Choteo in Sarduy's De donde son los cantantes, Chasqui 38(1), 16-28.

Birkenmaier, A. (2002). Travestismo latinoamericano: Sor Juana y Sarduy. Ciberletras: Revista de crítica literaria y de cultura, (7). Recuperado de http://www.lehman.cuny.edu/ciberletras/ v07/birkenmaier.html

Derrida, J. (2007). A Certain Impossible Possibility of Saying the Event. Critical Inquiry, 33(2), 441-461.

Derrida, J. (2002). Typewriter Ribbon: Limited Ink (2). En Peggy Kamuf. (Ed.), Without Alibi (pp. 71-160). Stanford: Stanford UP.

Echeverría, B. (2000). La modernidad de lo barroco. México, D.F.: Ediciones Era.

Esslin, M. (1961). The Theatre of the Absurd. Garden City, N.Y.: Doubleday.

Férez Mora, P. (2014). La sensualidad matérica: didáctica de la literatura de Severo Sarduy. Universidad de Murcia. Servicio de Publicaciones.

González Echevarría, R. (1987). La ruta de Severo Sarduy. Hanover: Ediciones del Norte.

González Echevarría, R. (2003). Introducción. En De donde son los cantantes (pp. 15-83). Madrid: Cátedra.

González Echevarría, R. (1987). Sarduy, the Boom, and the PostBoom. Latin American Literary Review, 15(29), 57-72.

Guerrero, G. (1996). Sarduy o la religión del vacío. Cuadernos Hispanoamericanos, (552), 33-46.

Guerrero, G. (2007). Severo Sarduy (1937-1993), retrato de un poeta en ocho fragmentos. En Severo Sarduy. Obras I Poesía (pp. 9-25). México: FCE. 
Joseph, B W. (2009). Azar, indeterminación, multiplicidad. En La anarquía del silencio: John Cage y el arte experimental (pp. 210238). Barcelona: MACBA.

Laddaga, R. (2007). Espectáculos de realidad. Ensayo sobre la narrativa latinoamericana de las últimas dos décadas. Rosario: Beatriz Viterbo.

Méndez Ródenas, A. (1983). Severo Sarduy: el neobarroco de la transgresión. México: UNAM.

Méndez Ródenas, A. (1978). Erotismo, cultura y sujeto en De donde son los cantantes. Revista Iberoamericana, 44(102), 45-63.

Montero, O. (1988). The Name Game: Writing/Fading Writer in De donde son los cantantes. Chapel Hill: University of North Carolina Press.

Moore-Gilbert, B. y Seed, J. (1992). Introduction. En Bart MooreGilbert y John Seed. (Eds.), Cultural Revolution? The Challenge of the Arts in the 1960s (pp. 1-14). London and New York: Routledge.

Moraña, M. (2010). Barroco/ Neobarroco/ Ultrabarroco. De la colonización de los imaginarios a la era postaurática: la disrupción barroca. En La escritura del límite (pp. 51-91). Vervuert: Iberoamericana.

Moreiras, A. (1991). Interpretación y diferencia. Madrid: Visor.

Olmedo, R. R. (2005). Ekphrasis and Spatial Form in Selected Works of Severo Sarduy. Diss. U of North Carolina-Chapel Hill.

Pérez, R. (2012). Severo Sarduy and the Neo-Baroque Image of Thought in the Visual Arts. West Lafayette, Ind.: Purdue UP.

Pérez, R. (2013). Severo Sarduy"s "Cuba": Invented, simulated and cross-dressed. Ciberletras. Recuperado de http://www. lehman.cuny.edu/ciberletras/v31/perez.htm.

Pino Estivill, E. (2015) Cuando Cuba entró en París: retombées barthesianas en la crítica literaria de Severo Sarduy. Mitologías hoy, (12), 163-175. 
Priestman, M. (1992). A Critical Stage: drama in the 1960s. En Bart Moore-Gilbert y John Seed. (Eds.), Cultural Revolution? The Challenge of the Arts in the 1960s (pp. 118-138). London and New York: Routledge.

Quesada, C. (2009). Severo Sarduy: en la patria de la página. En $L a$ metanovela hispanoamericana en el último tercio del siglo XX: las prácticas metanovelescas de Salvador Elizondo, Severo Sarduy, José Donoso y Ricardo Piglia (pp. 185-246). Madrid: Arco Libros.

Quevedo, F. de. (1981). Poesía varia. Madrid: Cátedra.

Rodenbeck, J. F. (2011). Radical Prototypes. Allan Kaprow and the Invention of Happenings. Cambridge \& London: MIT Press.

Rodríguez Monegal, E. (1970). Conversación con Severo Sarduy. Revista de Occidente, 31(92), 315-343.

Roszak, T. (1995). The Making of a Conter Culture: Reflections on the Technocratic Society and its Youthful Opposition. Berkeley: U of California P.

Sánchez, E. (2003). Glosas de identidad en De donde son los cantantes. En O. González. (Ed.), Severo Sarduy: escrito sobre un rostro (pp. 88-101). Camagüey: Ácana.

Sánchez Robayna, A. (1999) Cinco paneles para Severo Sarduy. En G. Guerrero y F. Wahl. (Eds.), Severo Sarduy. Obra Completa 2 (pp. 1771-1775). Madrid: ALLCA XX.

Sánchez Robayna, A. (2008). Figuraciones del Oriente en la poesía de Severo Sarduy. En G. Guerrero, X. L. García Canido y N. del Castillo. (Eds.), El Oriente de Severo Sarduy (pp. 49-59). Alcalá de Henares, Madrid: Instituto Cervantes.

Sánchez Robayna, A. (1995). La victoria de la representación: lectura de Severo Sarduy. Valencia, España: Centro de Semiótica y Teoría del Espectáculo: Episteme.

Santucci, S. y Grossi B. (2018). El color de la revolución. Sarduy, Robbe-Grillet y el mayo del '68. Revista Crítica Cultural, 13(1), 33-46. 
Sarduy, S. (1993). De donde son los cantantes. Madrid: Cátedra.

Sarduy, S. (1987). Ensayos generales sobre el Barroco. México: FCE.

Sarduy, S. (1999). Obra Completa. 2 Vols. México: FCE.

Sifuentes-Jáuregui, B. (2002). Transvestism, Masculinity, and Latin American Literature: Genders Share Flesh. Springer: Palgrave.

Sontag, S. (2001). Against Interpretation: And other Essays. Londres: Macmillan.

Sontag, S. (2013). Happenings: An Art of Radical Juxtaposition. En Essays of the 1960s \& 70s (pp. 248-258). New York, NY: Library of America.

Solotorevsky, M. (1994) El predominio escritural en un texto postmodernista: De donde son los cantantes de Severo Sarduy. Alba de América. Revista Literaria, (22-23), 183-191.

Spies, W. (1969). Vasarely. New York: H.N. Abrams.

Toledo, C. (2017). Literatura y artes visuales en tres escritores cubanos: Carpentier, Lezama y Sarduy. Boletín de arte, (17), 54-58.

Ulloa, J. (1985). Severo Sarduy: pintura y literatura. Hispamérica, 14(41), 85-94. 